\title{
The Role of Brand Trust in Determining The Relationship Between Brand Affection and Loyalty Programs on Customer Loyalty
}

\author{
Jojor Marintan Silalahi ${ }^{1}$, Lizar Alfansi $^{2}$, Akram Harmoni Wiardi ${ }^{3}$ \\ ${ }^{1,2,3}$ University of Bengkulu, Bengkulu, Indonesia
}

\begin{abstract}
This study investigates how brand affection, loyalty programs, and brand trust determine the loyalty in airways industry. We examined the influence of brand trust and brand affection on loyalty in airlines services. The airways companies applied loyalty programs as a trend. The purpose of the loyalty programs is to encourage the loyalty of the customers. The purpose of this study is to analyze the influence of brand affection and loyalty programs on brand trust and loyalty among GarudaMiles members. Primary data were collected through a survey. Data collected by online quistionnaire through social media and resulting 171 processable questionnaire. Data were analysed using confirmatory factor analysis and structural equation modelling. Confirmatory factor analysis within structural equation modeling were carried out to assess adequacy of the measurements and validity of the model. We found that brand affection is not significantly influence customer loyalty; brand affection significantly influence brand trust; and brand trust significantly influence customer loyalty. This result indicate that brand affection has an indirrect effect on loyalty, it's mediated by brand trust. Loyalty program is not significantly effect brand trust, it has direct effect on loyalty. It's become clear that only brand trust mediates the relationship of brand affection and loyalty. The customers of the airways companies tend to be loyal because of the loyalty programs applied by the airways companies. These finding add performance effectiveness and long-term relationships with customers in airlines industry to the factors needed to respond to the highly competitive situation at present, which will be even more important with the ASEAN Economic Community in 2015.
\end{abstract}

Keywords: Brand Affection, Brand Trust, loyalty, Loyalty Program

\section{INTRODUCTION}

In an growing competition environment, the brand becomes the most valuable asset. It is strategic and criticall for the company (Kabadayi and Alan, 2012). In the aviation industry, the industry continues to experience growth. International Air Transport Association (IATA) predict the global airline business net profit reached US \$ 25 billion in 2015. It grows up 25.6 percent compared with last year at \$19.9 billion. IATA predicts that the aviation industry in Indonesia will reach the 9th largest market in the world for domestic flights and for international flights Indonesia was ranked on sixth, the fastest growth of the international aviation market in the world's (http://industri.kontan.co.id). In Indonesia there are 17 
airlines that registered as the airlines that have fixed schedules and airport specific flight service.

Due to the growing number of airline company, the competition makes it difficult for airline company to increase the base customer and retain new customer. Loyalty has been identified as an important factor to predict the success of the company in relationship marketing (Griffin, 1996; Oliver, 1999). Oliver (1999) suggested that loyalty is an important factor to determine the success of a company. The company will be able to survive in a competitive market competition if they have loyal customer. Loyal customers would be willing to pay more and repurchase for its brands, they consider some unique value that no other brands can provide (Jacoby and Chestnut, 1978). This unique value derived from greater confidence of the brand capacity or it can be described as a positive affection when customers use the brand (Kabadayi and Alan, 2012).

Kabadayi and Alan (2012) suggested that the brand trust arrise after the customer evaluated companies offering. Customers would feel confidence with the brand if the company give assurance on safety, honesty and reliability of their brand (Doney \& Cannon, 1997). According to Lau and Lee (1999), the brand trust is the consumer's willingness to believe in the brand because there have more expectations to the brand that will give them good performance. The study on brand trust suggested that the high level of trust towards brand would lead to repurchase intention, brand satisfaction, loyalty and brand commitment.

The consumption of services began to be seen as something that involves feelings (affection). The feelings or emotions can be triggered by the customers experiences of services. Loyalty will be stronger under conditions of positive affection and will increase the positive attitude of consumers towards the brand (Dick and Basu, 1994). Lin and Lee (2012) suggested that brand affection would change customer's perceptions and beliefs on brand, reduce the perceived risk, and increase the level of confidence to the brand.

Air plane crash incident, Air Asia QZ8501 became the worse experience for aviation industry in Indonesia. Due to the indication of airline's flight schedule that was not official, these events led to poor air flight scheduling system. Because of that incident, recently every airline tries ro rebuild the customer's trust by establish the international safety standard and accomply the government's rules. One of Indonesian airlines that equiped by Operational Safety Audit (IOSA) origin of the International Air Transport Association (IATA) is Garuda Indonesia Airlines (http://hubud.dephub.go.id/?id/news/detail/2366). Garuda Indonesia is a state owned aviation enterprise (BUMN), which runs the service in the country and abroad. The airline has been operating since 1949 .

Currently the loyalty program is an important component strategy of customer relationship management (CRM). Loyalty program is a program that allows consumers to accumulate free rewards when they make repeat purchases with the company (Liu, 2007: 20). Loyalty program aims to increase loyalty by rewarding customers for doing business with the company. This is supported by Yi da Jeon (2003) which states that the purpose of loyalty program is to build loyalty by providing the benefit that can motivate the customers. A high appraisal to a 
company's loyalty program is the reflection of higher trust to the company (Ou et al., 2011).

Loyalty program was first used by American Airlines in 1999 under the name of Frequent Flyer Program. This is an entry point to the airline loyalty program. At Garuda Indonesia, loyalty program is called Garuda Frequent Flyer (GFF) which was established in 2001. In April 2014 GFF had been renamed as Garuda Miles that provide benefits and privileges to the profitable customer (www.garudaindonesia.com). IATA conclude that 14 percent of users of air transportation selected Frequent Flyer Program as their first reason in choosing an airline to travel (See Figure 1).

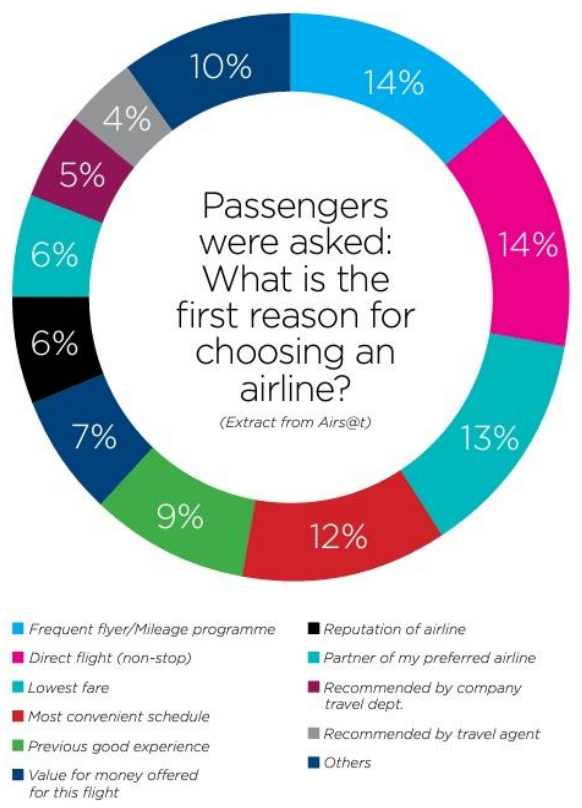

Figure 1 The Customer's First Reason for Choosing An Airline

This trend is also seen in the membership of Garuda Miles and recently reached 1 million members from six levels of membership, including Junior, Blue, Silver, Gold, EC Plus, and Platinum (http://ekbis.sindonews.com/read/847960/34/garuda-targetkan-peningkatan-50kartu-anggota-1395835326). Currently customers require positive brand affection so that they can feel comfortable in traveling and indirectly improve the trust and loyalty. Loyalty program which is currently being trend in the airlines industry, it is also one aspect in increasing loyalty.

The purpose of this study was to examine the influence of brand affection to loyalty on GarudaMiles users, examine the influence of loyalty programs on loyalty, examines the effect of brand affection on brand trust, examine the influence 
of loyalty programs on brand trust, and examine the effect of brand trust on loyalty of GarudaMiles users. We propose the model that describes the relationship between brand affection, lotalty programs, brand trust, and loyalty.

\section{LITERATURE STUDY AND HYPOTHESIS DEVELOMPMENT}

\subsection{Brand Affection}

Brand is a company's long-term assets (Wood, 2000). With the difference in brand name and specifications of each product or services and if the product or services with a 'brand' name that brings satisfaction and loyalty, the brand will generate revenue from the sale of its products and can be a long-term asset for the company. In the development of brand, the brand of affection also be a comprehensive study in the marketing literature (Iglesias et al., 2011). Hulten (2011) argues that emotional connection between brands and customers is important in building a strong brand in the minds of customers. Brand affection are connected with emotional expressions or feelings of consumers (Law et al., 2009), emotion is a major factor in affective perspective. Chaudhuri and Holbrook (2001: 82) defines brand affection as perspective of potential brand to get a positive emotional responses on customer as a result of the experience toward a product or services. In other words, brand affections can be described as an emotional response of consumers towards a brand in consequence of having experience with the brand.

\subsection{Loyalty Programs}

One of the most valuable marketing strategy in which executives can expand is a loyalty program, which is a promotion plan designed to increase loyalty by providing incentives to customers through benefits (Yi and Jeon, 2003). Loyalty programs have become an important component of customer relationship management (CRM) because it is considered very effective in retaining customers and readily accepted both by customers and retailers (Bose and Rao, 2011; Liu and Yang, 2009). Through this program, the company has the potential having customers repurchase intention and at the same time, acquire loyal consumer data that can assist future efforts. In some industry in which a variety of loyalty programs offered, these programs prompting a stiff competition.

Uncles et al., (1997) states that the loyalty program is important in increasing the overall value of the product or service because they motivate loyal buyers to make future purchases. Liu (2007: 20) defines loyalty program as a program that allows consumers to accumulate free rewards when they make repeat purchases with the company.

The program is intended to encourage loyalty from time to time. Moreover, the loyalty program not only helps build customer commitment, but also demonstrates the company's commitment (Liu, 2007). Frequent Flayer program was first used by American Airlines in 1991. Today, it is a form of loyalty program that is being implemented by many airline companies. The basic aim of this program is to encourage people to use the same airline companies as they travel (Colakoglu and Artuger, 2013). Kopalle and Neslin (2003) concluded that the 
program frequentflyer increase the product value of an airline and an increase in consumer demand for airlines that offer such programs.

\subsection{Brand Trust}

Many research conducted in the various disciplines (psychology, economics, sociology, and others) related to the concept of trust, where the perspectives and definitions of the trust is in accordance with their respective fields (Ayidin et al., 2014). In most studies related to trust, emphasized that trust is necessary to formalize and retain a good long-term relationship (Quinton and March, 2008).

Delgado-Ballester et al., (2003) confirmed that customer's trust in a brand are based on the perception that the brand is consistent and responsible for the benefit and welfare of customers. Herbst et al., (2011) describes brand trust as a customer's belief to a product, or services companies that are reliable and competent.

According to Lau and Lee (1999), there are three factors that affect trust in the brand, namely:

1. Brand Characteristic

Brand characteristic has a very important role in determining the customer's decision to trust a brand. Customer make an assessment before buying. Brand characteristics related to brand trust are predictable, reputable, and competent.

2. Company Characteristic

Company Characteristic can also affect the level of consumer trust in brand. Consumer knowledge about the company's image is a pre-consumer understanding of a product. These characteristics include the company's reputation, the company desired motivation, and integrity of the company.

3. Consumer Brand Characteristic

Are the two groups who interact. Therefore, the consumer brand characteristics can influence trust to the brand. These characteristics include the similarity between the concept of emotional consumer brand personality. Customer will evaluate and assess a brand if a brand has congruencies.

The existence of consumer trust to a brand will create a sense of pleasant and reduce consumers' perception of risk. Build and maintain customer trust towards the brand is very important, because it is the key to successful long-term relationship between the company and customers. Research on brand trust has supported that the high level of trust towards the brand leads to repurchase the brand, brand satisfaction, brand loyalty and brand commitment (Lau and Lee, 1999; Delgado-Ballesteret al., 2000). Customers who believe that a brand can meet the expected performance, will tend to more often use a single brand instead of using other brands.

\subsection{Loyalty}

Loyalty in the service industry has focused primarily in the marketing management theory and practice (Ruyter and Blomer, 1999). Loyalty can act as a barrier to customer switching behavior and have an impact on the development of sustainable competitive advantage (Gremler and Brown, 1996). Loyalty has been identified as an important factor for a company's success in marketing (Oliver, 1993). Dick and Basu (1994) states that loyalty created by the relationship between 
attitude to purchase and between attitudes to behavior, there are four conditions of loyalty, namely:

1. True loyalty, related on attitudes and repeat purchase.

2. Latent loyalty, associated with high attitude, but low repeat purchase.

3. Spurious loyalty, associated with a low attitude, with a high repeat purchase.

4. No loyalty, associated with a low attitude, combined with low purchase.

Oliver (1999) suggests that loyalty is a commitment that is firmly held by the consumer to repurchase consistently in the future, thereby causing repetitive purchase the same brand despite the influence of the environment that has the potential effect for them to switch. According to Liu (2007) loyalty is a positive feeling toward the brand and a strong dedication to buy a product or service many times now and next of the same brand, regardless of the actions of competitors or environmental changes.

Griffin (1995) concluded that customer relationship to the company and its products is determined by two factors, namely preferences (the level of consumer trust in product or services) and the perception of product differentiation (the extent to which consumers see different companies and their products with alternative options on the market).

\subsection{Hypothesis Development}

After using a product, consumers will have an emotional response to their experience on the brand. Affection positively is associated with greater commitment to loyalty (Lin and Lee, 2012). Those who have a positive affection on the brand or support the brand with her feelings are more likely to maintain a relationship with the brand (Fullerton, 2005). Chaudhuri and Holbrook (2001: 82) defines a brand affection as a potential brand to get a positive emotional response to the consumer as a result of customer's experiences of a product or services. They show that the strong value of the products categorized as directly related to the brand affection and is one important factor in building loyalty. This shows that loyalty will be greater under conditions of a positive emotional affection that will increase positive attitudes of customers to the brand (Dick and Basu, 1994). Based on our review of the literature we formulate the following hypothesis:

\section{H1: Brand affection have a positive effect on brand loyalty.}

Appropriate loyalty programs not only increases customer trust that can be reflected in sales growth, it's also contribute to increase the interaction between the business and the customer (Huang and Wonglorsaichon, 2013). Omar et al., (2009) conclude that the existing benefits in the loyalty program is a determinant in satisfaction assessment program, and plays an important role to determine loyalty. Ou et al., (2011) confirm that loyalty programs have an influence on loyalty. Yi and Jeon (2003) believe that loyalty program is a marketing plan designed to increase loyalty by providing incentives to customers through additional benefits. A successful loyalty program will further strengthen relationships with customers. Based on literature review above, we propose the following hypothesis:

H2: Loyalty programs have a possitive effect on brand loyalty. 
Although the concept of brand trust and brand affection have an influence on both brand loyalty, but both have different characteristics. Chaudhuri and Holbrook (2001) states that brand trust involves a process that is well consider, while the development of brand affection is spontaneously. Customers tend to use positive and negative affection as a source of information (FedorikhindanCole, 2004). When consumers feel positive affection towards a brand, they will believe that the brand reliable, trustworthy, and they thought it would be willing to give priority to the customer's benefit. Brand affection can change perceptions and user's belief to the brand, reduce the perceived risk, and increase the level of trust towards the brand (Lin and Lee, 2012). Based on literature review, we propose the following hypothesis:

\section{H3: Brand affection have a positive effect on brand trust.}

Some researchers believe that loyalty programs affect the customer's trust to a brand (Ou et al.,. 2011; Huang and Wonglorsaichon, 2013). In this case, customers believe that they can receive a higher economic value, variety of awards system, and the chance to win prizes through the implementation of the company's loyalty program. Therefore, when customers appreciate a high value to a company's loyalty program, they also reflect a higher level of trust towards the brand (Ou et al., 2011). Based on literature review, we propose the following hypothesis:

\section{H4: Loyalty program have a positive effect on brand trust.}

Brand is a sign of trust, it can became a symbol of quality and assurance in building trust (Bart et al., 2005). The importance of building trust has been shown to support long-term relationship between buyers and sellers can trust is consumer confidence that he can rely on the seller to provide the promised services (Agustin and Singh, 2005). Trust is very important in building a strong relationship between consumers and brands, and have a positive relationship on loyalty (Lau and Lee, 1999; Urban et al., 2000). Research on brand trust has supported that the high level of trust towards the brand leads to repurchase intention, brand satisfaction, brand commitment, and loyalty (Lau and Lee, 1999; Delgado-Ballester et al., 2000). Based on our review of the literature we formulate the following hypothesis:

\section{H5: Brand trust have positive effect on loyalty.}

\section{RESEARCH METHODOLOGY}

The design of this study was empirical study. We collected data via online survey among GarudaMiles members. We use non-probability sampling conducted by snowball sampling technique. This technique shows the customers criteria of Garuda Indonesia Airlines loyalty program (GarudaMiles). Customers who are not the members of GarudaMiles could not be the respondents in the study. We distribute 189 questionnairs to the members of GarudaMiles, and only 171 questionnaires are eligible to proceed. 
Table 1 List of The Respondents

\begin{tabular}{|c|c|c|}
\hline Demography & Frequency & Percent \\
\hline \multicolumn{3}{|l|}{ Gender } \\
\hline Male & 78 & $45,6 \%$ \\
\hline Female & 93 & $54,4 \%$ \\
\hline \multicolumn{3}{|l|}{ Age } \\
\hline $21-30$ & 82 & $48,0 \%$ \\
\hline $31-40$ & 51 & $29,8 \%$ \\
\hline $41-50$ & 35 & $20,5 \%$ \\
\hline$>50$ & 3 & $1,8 \%$ \\
\hline \multicolumn{3}{|l|}{ Income per-month } \\
\hline$<5$ Million & 46 & $26,9 \%$ \\
\hline 5 Million- 9 Million & 103 & $60,2 \%$ \\
\hline 10 Million - 15 Million & 19 & $11,1 \%$ \\
\hline 16 Million - 20 Million & 3 & $1,8 \%$ \\
\hline
\end{tabular}

Source: processed data 2015

Based on Table 1, it shows that the respondents as the member of GarudaMiles are 93 respondents were female and 78 respondents were male, with an age range of the most dominant in group between 21-30 years (82 respondents). Most respondents are who have income between 5 million to 9 million Rupiah (103 respondents or $60,2 \%$ of the total respondents).

To test the hypothesis proposed in this study we use Stuctural Equation Modeling (SEM) as an analytical technique. Before we perform hypothesis testing, we examine the measurement model on the validity and reliability of each construct, we use convergent validity and construct reliability technique to perform the examination.

\section{RESULTS}

\subsection{Validity And Reliability}

To test the validity of each construct, we use convergent validity. Convergent validity can be measured through measurement model of CFA, this technique used to determine whether each indicator is estimated to be a valid measurement of the concepts. Hair et al., (1998: 111) suggested the value of the loading factor that are greater $+0,30$ fulfilled the minimum level, the value of loading factor $+0: 40$ is considered better, and the loading factor $>0,50$ is considered to be significant.

Based on Table 2, the indicator BT1 and L1 has a loading factor value less than 0,40 , so that both indicators do not meet the convergent validity as a indicant of their latent constructs. Therefore, following the advice of Raghunathan et al., (1999) which suggested that if the values of loading factor under 0,40 then these indicators should be excluded from the analysis as well. We perform the CFA test after the deletion of the indicator that have loading factor values less than 0,4 . 
The Role of Brand Trust in Determining The Relationship Between Brand Affection and Loyalty Programs on Customer Loyalty

Table 2 The Results of Construct Validity Test

\begin{tabular}{|c|c|c|c|c|}
\hline Constructs & \multicolumn{3}{|c|}{ Indicators } & Estimate \\
\hline \multirow{4}{*}{ Brand Affection } & BA4 & $<--$ & $\mathrm{BA}$ &, 463 \\
\hline & BA3 & $<---$ & $\mathrm{BA}$ & ,723 \\
\hline & BA2 & $<---$ & $\mathrm{BA}$ & ,438 \\
\hline & BA1 & $<---$ & $\mathrm{BA}$ & ,458 \\
\hline \multirow{4}{*}{ Loyalty Program } & LP4 & $<--$ & LP & ,735 \\
\hline & LP3 & $<---$ & LP & ,797 \\
\hline & LP2 & $<---$ & LP & ,641 \\
\hline & LP1 & $<--$ & LP & ,649 \\
\hline \multirow{4}{*}{ Brand Trust } & BT4 & $<--$ & BT & ,652 \\
\hline & BT3 & $<---$ & BT &, 570 \\
\hline & BT2 & $<--$ & BT & ,429 \\
\hline & BT1 & $<---$ & BT & ,124 \\
\hline \multirow{4}{*}{ Loyalty } & $\mathrm{L} 4$ & $<--$ & $\mathrm{L}$ & ,690 \\
\hline & L3 & $<--$ & $\mathrm{L}$ &, 870 \\
\hline & L2 & $<--$ & $\mathrm{L}$ & ,601 \\
\hline & L1 & $<--$ & $\mathrm{L}$ &, 362 \\
\hline
\end{tabular}

Source: processed data 2015

Table 3 shows that the factor loading value for each indicator of each construct is higher than 0.4. It can be concluded that the indicators of each construct is valid. We assess construct reliability by measuring the instruments used on reliability index (composite reliability) of structural equation modelling. The limitation values to assess a level of reliability that is acceptable at least 0.70 (Hair, et al., 1998).

Table 3 The Results of Construct Validity Test After The Deletion of Indicator BT1 and L1

\begin{tabular}{|c|c|c|c|c|}
\hline Variabel & \multicolumn{3}{|c|}{ Indicators } & Estimate \\
\hline \multirow{4}{*}{ Brand Affection } & BA4 & $<--$ & $\mathrm{BA}$ &, 470 \\
\hline & BA3 & $<---$ & BA & ,718 \\
\hline & BA2 & $<--$ & $\mathrm{BA}$ & ,435 \\
\hline & BA1 & $<--$ & BA & ,458 \\
\hline \multirow{4}{*}{ Loyalty Program } & LP4 & $<--$ & LP & ,731 \\
\hline & LP3 & $<---$ & LP & ,796 \\
\hline & LP2 & $<---$ & LP & 644 \\
\hline & LP1 & $<---$ & LP & ,651 \\
\hline \multirow{3}{*}{ Brand Trust } & BT4 & $<--$ & BT & 622 \\
\hline & BT3 & $<--$ & BT & ,629 \\
\hline & BT2 & $<--$ & BT & ,434 \\
\hline \multirow{2}{*}{ Loyalty } & & $<---$ & $\mathrm{L}$ & ,672 \\
\hline & L3 & $<--$ & $\mathrm{L}$ & ,918 \\
\hline
\end{tabular}


The Role of Brand Trust in Determining The Relationship Between Brand Affection and Loyalty Programs on Customer Loyalty

\begin{tabular}{ccccc}
\hline Variabel & \multicolumn{3}{c}{ Indicators } & Estimate \\
\hline & L2 & $<---$ & L &, 586 \\
\hline
\end{tabular}

Source: processed data 2015

We use the minimum CR (Construct Reliability) proposed by Ferdinand (2002) which suggested that the variable is reliable if it had an alpha reliability coefficient of 0.5 or higher. Based on Table 4 , it shows that all construct are reliable because each latent construct have a reliability coefficient greater than 0.50 .

Table 4 Construct Reliability

\begin{tabular}{lc}
\hline \multicolumn{1}{c}{ Construct } & Value \\
\hline Brand Affection & 0,60187 \\
Loyalty Program & 0,79979 \\
Brand Trust & 0,58320 \\
Loyalty & 0,77657 \\
\hline
\end{tabular}

Source: processed data 2015

\subsection{Measurement Model}

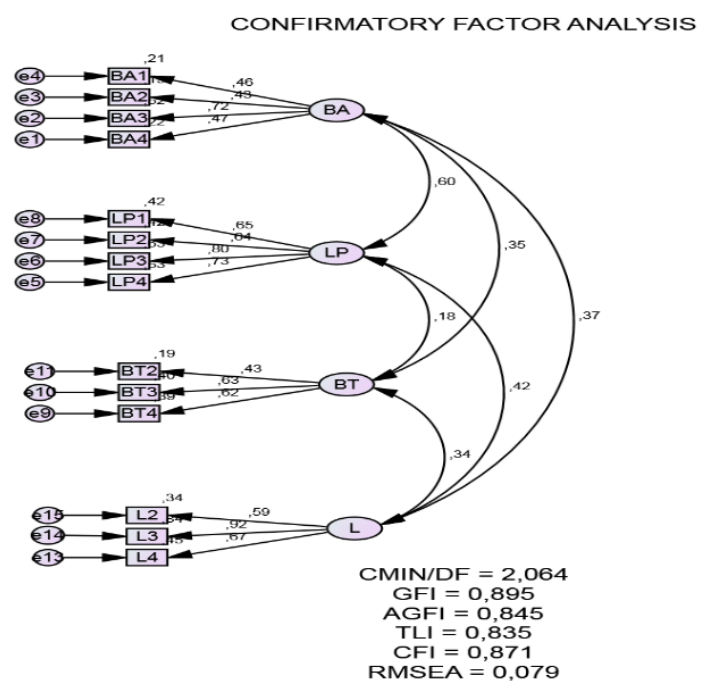

Figure 2 Confirmatory Factor Analysis of Measurement Models

The results of confirmatory factor analysis of measurement models in Figure 2 shows that the value of the measurement criteria of goodness-of-fit look much better. RMSEA value of 0.079 , GFI=0.895, AGFI=0.845, CMIN/DF=2.064, $\mathrm{TLI}=0.835$, and $\mathrm{CFI}=0,871$. The goodness of fit of measurement models indicates that all constructs are fit.

\subsection{Structural Equation Modelling}

The results of data processing for the structural model analysis are shown in Figure 3. 


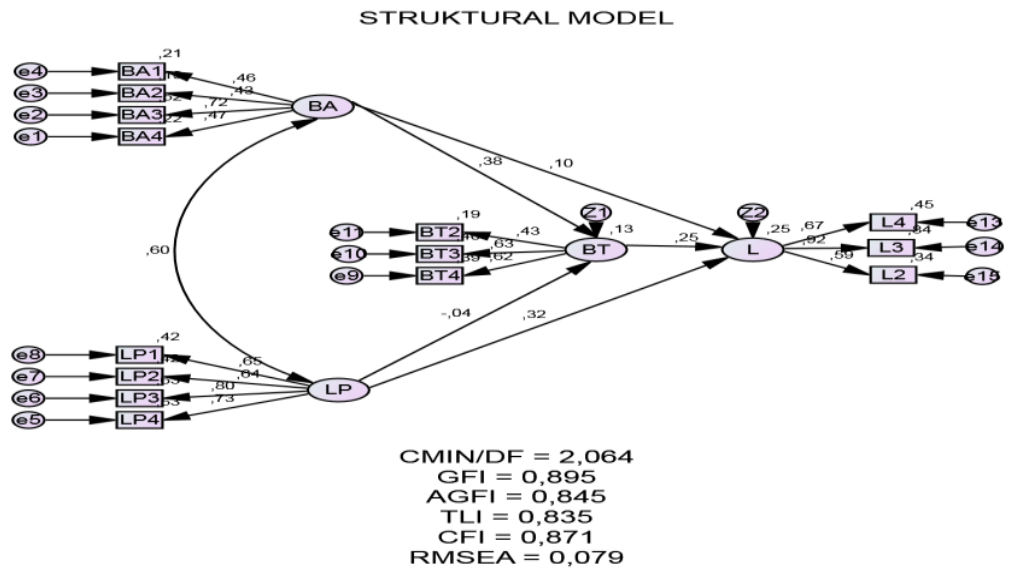

Figure 3 The Results of Structural Equation Modelling

Table 5 Goodness of Fit Index

\begin{tabular}{lccc}
\hline \multicolumn{1}{c}{ Goodness-of-fit } & Cut off value & Results & Declaration \\
\hline RMSEA & $\leq 0.08$ & 0,079 & Good \\
GFI & $\geq 0.90$ & 0,895 & Marginal \\
AGFI & $\geq 0.90$ & 0,845 & Marginal \\
CMIN / DF & $\leq 2.00$ & 2,064 & Marginal \\
TLI & $\geq 0.95$ & 0,835 & Marginal \\
CFI & $\geq 0.95$ & 0,871 & Marginal \\
\hline
\end{tabular}

Source: processed data 2015

Table 5 shows that six index goodness-of-fit index has met the standard cutoff value that are recommended. The values of $\mathrm{RMSEA}=0.079$ while the recommended value of RMSEA is equal to or less than 0.08. Therefore, we conclude that the value of goodness-of-fit is good. GFI value obtained at 0.895 while the value recommended by GFI is equal or higher than 0.90 . It indicates that the value is marginal because the GFI are closer to the recommended value. AGFI value are equal or higher than 0.90. AGFI value as presented in Table 5 are 0.845 it shows that the value is marginal, because the value closer to the recommended value of AGFI. The value of $\mathrm{CMIN} / \mathrm{DF}=2.064$ while recommend value for CMIN/DF are equal to or higher than 2.00. Because the value of CMIN/DF are higher than 2,00 and still be within the tolerance level of the recomended value. Based on the value of CMIN/DF in Table 5, the model in this study is still acceptable. The recommended value of TLI are $\geq 0.95$ and the value of TLI in this study are 0.835 . The TLI value is less than 0.95 and still be within the tolerance level. It shows that the TLI value is marginal and closer to the recommended TLI. The recommended value of CFI are $\geq 0.95$ and the value of $\mathrm{CFI}=0.871$. It shows that the value is marginal, because the value are closer to the recommended CFI.

\subsection{Hypothesis Testing}

We perform the analysis of the correlation and significance level betweenconstruct which indicated by the Probability level (p), Standardize 
Estimate, and Critical Ratio (C.R.) betweenconstruct. The statistical testing results shown in Table 6.

Table 6 Regression Weight of Structural Equation Modelling

\begin{tabular}{lcccccc}
\hline \multicolumn{2}{c}{ Construct } & Estimate & S.E. & C.R. & p \\
\hline BT & $<---$ & BA &, 495 &, 240 & 2,063 &, 039 \\
BT & $<---$ & LP &,- 026 &, 111 &,- 230 &, 818 \\
L & $<---$ & BA &, 138 &, 216 &, 640 &, 522 \\
L & $<---$ & BT &, 274 &, 129 & 2,133 &, 033 \\
L & $<---$ & LP &, 226 &, 095 & 2,366 &, 018 \\
\hline
\end{tabular}

Table 6 shows the Critical Ratio value betweenconstruct Brand Affection (BA) and Loyalty (L) are 0.640, Standardize Regression Weight Estimate $=0.138$ $(\mathrm{p}>0,05)$ it is indicate that Brand Affection (BA) has no significant effect on loyalty (H1=Not Supported).

The Critical Ratio value betweenconstruct Loyalty Program (LP) and Loyalty (L) are 2.366, Standardize Regression Weight Estimate $=0.226(\mathrm{p}<0,05)$ it is indicate that Loyalty Program (LP) has a positive and significant effect on loyalty $(\mathrm{H} 2=$ Supported).

The Critical Ratio value betweenconstruct Brand Affection (BA) and Brand Trust (BT) are 2.063, Standardize Regression Weight Estimate $=0.495(\mathrm{p}<0,05)$ it is indicate that Brand Affection (BA) has a positive and significant effect on Brand Trust (BT) $(\mathrm{H} 3=$ Supported).

The Critical Ratio value betweenconstruct Loyalty Program (LP) and Brand Trust $(B T)=-0.230$, Standardize Regression Weight Estimate $=-0.26(p>0,05)$ it is indicate that Loyalty Program (LP) has no significant effect on Brand Trust (BT) (H4= Not Supported).

The Critical Ratio value betweenconstruct Brand Trust (BT) and Loyalty $(\mathrm{L})=$ 2.133, Standardize Regression Weight Estimate $=-0.274(\mathrm{p}<0,05)$ it is indicate that Brand Trust (BT) has positive and significant effect on Loyalty (H5= Supported).

\section{DISCUSSION}

1. The effect of brand affection on brand loyalty

The consumption of services began to be seen as something that involving feelings (affection). Feelings or emotions can be determined by customer's experiences of certain services. Brand affection are important, because the customer who have a positive affection on brand or support the brand with her feelings may to maintain good relationships with the brand rather than the customer who had negative affection (Fullerton, 2005). The results in this study shows that there is no association between the brand affection and loyalty in the cotext of GarudaMiles Members, it means that if the members of GarudaMiles have positive or negative affectiion, it will not effect their loyalty towards service provider. Song 
et al. (2012) confirm that the brand affection has no significant effect in increasing loyalty. However, significantly increase the brand trust and then will increase significantly on loyalty. There is an indirrect effect of the brand affection to loyalty, it is mediated by brand trust. It's need to be consider that the companies capability to build loyalty is not enough just to increase customers' positive affection but will need additional triggers such as increasing customer trust.

2. The effect of loyalty programs on loyalty

Liu (2007: 20) defines loyalty program as a program that allows consumers to accumulate free rewards when they make repeat purchases with the company. The results showed that the loyalty program (GarudaMiles) increase the loyalty of GarudaMiles members. This finding consistent with Omar et al. (2009) which propose that the existing benefits in the loyalty program is a key determinant in satisfaction assessment program, and plays an important role in the formation of loyalty. Yi and Jeon (2003) states that the loyalty program is a marketing plan designed to increase loyalty by providing incentives to customers through additional benefits. This finding support the various theories and research results that can be concluded that the loyalty program has a positive effect on loyalty of GarudaMiles members in Indonesia.

3. The effect of brand affection on brand trust

The customers whose feel positive affection towards a brand would believe that the current brand are reliable, trustworthy, and would be willing to give priority to the customer's benefit. Brand affection can change the perceptions and customer's trust to the brand as well as reduce the perceived risk and improve the level of trust towards the brand (Lin and Lee, 2012). This research support Lin and Lee (2012); Chaudhuri and Holbrook (2001) and Song et al. (2012) which conclude that the brand affection positively influence brand trust.

4. The effect of loyalty programs on brand trust

Basically, customers believe that they can receive a higher economic value, the variety of awards, and the chance to win prizes through the implementation of the company's loyalty program (Ou et al., 2011). The results of this study showed that loyalty programs did not significantly affect the brand trust in the context of GarudaMiles's members. The members of loyalty program tend to be focus on loyalty program that give them more benefit rather than increasing their trust in brand. This finding consistent with Wright and Sparks (1999) in Liu (2007) which suggested that the biggest attraction for customers to participate in a loyalty program is the reward program and free benefit program. They do not focus on company's reputation but they intended to get the reward provided by the company for each purchase.

5. The effect of brand trust on loyalty

Trust is very important in building a strong relationship between consumers and brands. It has a positive effect on loyalty (Lau and Lee, 1999; Urban et al., 2000). The result of this study shows that there is a positive relationship between brand trust and loyalty. This study support the research on brand trust that suggested that the high level of trust towards the brand leads to customer's repurchase intention, satisfaction, loyalty, and commitment to the brand (Lau and 
Lee, 1999; Delgado-Ballester et al., 2000; Urban et al., 2000). This finding confirmed that if the customer trust on a companies is high it would be necessary that they would stay on incumbend service provider.

\section{CONCLUSION}

We conclude that customer loyalty in the airlines industry are determined by the willingness of the customer to have positif affection and should be supported by customer's trust on a company. Brand affection has an influence on brand trust. The brand affections perceived by Garuda Indonesia customer as feeling good, happy, and calm during the flight can build their trust to fly with Garuda Indonesia. Although brand affections are important in increasing competitiveness in airlines industry, but brand trustworthyness is also an important factor in increasing loyalty. Loyalty program directly effect the loyalty, with reward and attractive prizes for customers through this loyalty programs Garuda Indonesia would retain and keep customers loyal in the future. Loyalty program that has been done should be continuously upgraded in accordance with the needs of current customers, so that customers will be more interested when collecting Miles. Good communication through each account owner GarudaMiles also very important to be maintained. Customer perception on brand trust has an influence on customer loyalty, the confidence feeling or trust would encourage the willingness to repurchase Garuda Indonesia services in the future and build up more commitment.

\section{References}

Aaker, D.A. (1996). Measuring Brand Equity Accros Product and Markets. California Management Review, 38(3), 102-120.

Abraham, M.L., \& Littrell, M.A. (1995). Consumers' Conceptualization of Apparel Attributes. Clothing and Textile Research Journal, 13, 65-74.

Agustin, C., \& Singh, J. (2005). Curvilinear Effects of Consumer Loyalty Determinants in Relational Exchanges. Journal of Marketing Research.

Alfansi, L. (2012). Pemasaran Jasa Finansial. Jakarta: Salemba Empat.

Anwar, A., Amir, G., Sohail, F.B., \& Akram, S.N. (2011). Impact of Brand Image, Trust, and Affect on Consumer Brand Extension Attitude: The Mediating Role of Brand Loyalty. International Journal of Economics and Management Sciences, 1(5), 73-79.

Ayidin, G., Ar, A.A., \& Taskin, C. (2014). The Role of Brand Trust on Parent's Purchase Intention of Baby Care Product. Doğuş Üniversitesi Dergisi, 15(2), 165-180.

Bart, Y., Shankar, V., Sultan, F., \& Urban, G. Are the drivers and the role of online trust the same for all web sites and consumers?: A large-scale exploratory empirical study. Journal of Marketing, 69(4), 133-152.

Bollen, K.A. (1990). Overall Fit in Covariance Structure Models: Two Types of Sample Size Effects. Psychological Bulletin, 107(2), 256-59.

Chaudhuri, A., \& Holbrook, M.B. (2001). The Chain of Effect from Brand Trust and Brand Affect to Brand Performance: The Role of Brand Loyalty. Journal of Marketing, 65, 81-93. 
Colakoglu, O.E., \& Artuger, S. (2013). The Effect of Frequent Flyer Program on Customer Loyalty. The International of Social Sciences, 12(1), 33-43.

Delgado-Ballester, E., Munuera-Aleman, J.L., \& Yague-Guillen, M.J. (2003). Development and validation of a brand trust scale. International Journal of Market Research, 45(1), 35-53.

Dick, A.S., \& Basu, K. (1994). Customer Loyalty: Toward an Integrated Framework. Journal of Academy of Marketing Science, 22, 99-113.

Duncan, O.D. (1975). Introduction to Structural Equation Models. New York: Academic Press.

Eisingerich, A.B., \& Rubera, G. (2010). Drivers of Brand Commitment: A CrossNational Investigation. Journal of International Marketing, American Marketing Association, 18( 2), 64-79.

Fedorikhin, A., \& Cole, C. A. (2004). Mood Effects on Attitudes, Perceived Risk and Choice: Moderators and Mediators. Journal of Consumer Psychology, 14, 2-12.

Ferdinand, A. (2002). Structural Equation Modeling Dalam Penelitian Manajemen. (In Indonesian). Semarang: Badan Penerbit Universitas Diponegoro.

Ferdinand, A. (2006). Metode Penelitian Manajemen. Semarang: Badan Penerbit Universitas Diponegoro.

Fullerton, G. (2005). The Impact of Brand Commitment on Loyalty to Retail Service Brands. Canadian Journal of Administrative Sciences, 22(2), 97110.

Gremler, D.D., \& Brown, S.W. (1996). Service Loyalty: Its Nature, Importance, and Implications.

Grewal, D., Krishnan, R., Baker, J., \& Borin, N. (1998). The Effect of Store Name, Brand Name, and Price Discounts on Consumer's Evaluations and Purchase Intentions. Journal of Retailing, 74(3), 331-352.

Griffin, J. (1996). The Internet's Expanding Role in Building Customer Loyalty. Direct Marketing, 159, 50-53.

Hair, Jr.J.F., Anderson, R.E., Tatham, R.L., \& Black, W.C. (1998). Multivariate Data Analysis (Fifth Edition). New Jersey: Prentice-Hall, Inc.

Herbst, K.C., Finkel, E.J., Alan, D., \& Fitzsimons, G. M. (2011). On the Dangers of Pulling a Fast One: Advertisement Disclaimer Speed, Brand Trust, and Purchase Intention. Journal Of Consumer Research, 38, 909-919.

Huang, X., \& Wonglorsaichon, P. (2013). The Effect of Customer Loyalty Program and Service Quality on Customer Loyalty in Bangkok. School of Business, University of the Thai Chamber of Commerce, Thailand.

Hulten, B. (2011). Sensory Marketing: The Multi-Sensory Brand-Experience Concept. European Business Review, 23(3), 256-273.

Holbert, R.L., \& Stephson, M.T. (2002). Structural Equation Modeling in the Communication Sciences, 1995-2000. Human Communication Research, 28(4), October, 531-551.

Iglesias, O., Singh, J.J., \& Batista-Foguet, J.M. (2011). The Role of Brand Experience and Affective Commitment in Determining Brand Loyalty. Journal of Brand Management, 18(8), 570-582.

Jacoby, J.W., \& Chestnut, R.W. (1978). Brand Loyalty Measurement and Management. 
Kabadayi, E.T., \& Alan, A.K. (2012). Brand Trust and Brand Affect: Their Strategic Important on Brand Loyalty. Journal of Global Strategic Management, 11, 80-86.

Kopalle, P.K., \& Neslin, S.A. (2003). The Economic Viability of Frequency Reward Programs in a Strategic Competitive Environment. Review of Marketing Science, 1, 1-39.

Lau, G.T., \& Lee, S.H. (1999). Consumers' Trust in a Brand and The Link to Brand Loyalty. Journal of Market Focused Management, 4, 341-370.

Law, D., Wong, C., \& Yip, J. (2009). How Does Visual Merchandising Affect Consumer Affective Response?: An Intimate Apparel Experience. European Journal of Marketing, 46(1), 112-133.

Lin, M.Q., \& Lee, B.C.Y. (2012). The Influence of Website Environment on Brand Loyalty: Brand Trust and Brand Affect as Mediators. International Journal of Electronic Business Management,10(4), 308-321.

Liu, Y. (2007). The Long-term Impact of Loyalty Programs on Consumer Purchase Behavior and Loyalty. Journal of Marketing, 71(4), 19-35.

Morgan, R.M., \& Hunt, S.D. (1994). The Commitment Trust Theory of Relationship Marketing. Journal of Marketing, 58(3), 20-38.

Mosavi, S.A., \& Kenarehfard, M. (2013). The Impact of Value Creation Practices on Brand Trust and Loyalty in a Samsung Galaxy Online Brand Community in Iran. Mobile Marketing Association, IJMM Winter, 8(2), 75-84.

Oliver, R. L. (1993). Whence Consumer Loyalty?. Journal of Marketing, 63(4), 33-44.

Ou,W.M., Shih, C.M., Chen, C.Y., \& Wang, K.C. (2011). Relationships Among Customer Loyalty Programs, Service Quality, Relationship Quality and Loyalty. Chinese Management Studies, 5(2), 194-206.

Quinton, S., \& March, S.H. (2008). Trust and Online Wine Purchasing: Insights into UK Consumer Behavior. International Journal of Wine Business Research, 20(1), 68-85.

Raghunathan, B., Ragghunathan, T.S., \& Tu, Q. (1999). Dimensionality of The Strategic Grid Framework: The Construct and Its Measurement. Information Systems Research, 10(4), 343-355.

Ringberg, T., \& Gupta, S. (2003). The Importance of Understanding the Symbolic World of Customers in Asymmetric Business-to-Business Relationships. Journal of Business and Industrial Marketing, Special Issue on Qualitative Approaches in B-2-B, 18(6), 607-626.

Sahin, A., Zehir, C., \& Kitapci, H. (2011). The Effects of Brand Experiences, Trust and Satisfaction on Building Brand Loyalty; An Empirical Research On Global Brands. Procedia Social and Behavioral Sciences, 24, 1288-1301.

Sekaran, U. (2006). Research Method for Business: A Skill Building Approach. United Kingdom: John Wiley \& Sons, Inc.

Sirdeshmukh, D., Singh, J., \& Bary, S. (2002). Consumer Trust, Value, and Loyalty in Relational Exchanges. Journal of Marketing, 66, 15-37.

Song, Y., Hur, W., \& Kim, M. (2012). Brand Trust and Affect in the Luxury BrandCustomer Relationship. Social Behavior And Personality, 40(2), 331-338.

Sung, Y., \& Kim, J. (2010). Effects of Brand Personality on Brand Trust and Brand Affect. Psychology and Marketing, 27(7), 639-661. 
Uncles, M.D., Dowling, G.R., \& Hammond, K. (2003). Customer Loyalty and Customer Loyalty Programs. Journal of Consumer Marketing, 20(4), 294316.

Urban, G. L., Sultan, F., \& Qualls, W. J. (2000). Placing Trust at The Center of Your Internet Strategy. Sloan Management Review, 42, 39-49.

Williamson, M. (2002). Emotions, Reason and Behavior: A Search for The Truth. Journal of Consumer Behavior, 2(2), 196-202.

Wood, L. (2000). Brands and Brand Equity: Definition and Management. Management Decision, 38(9), 662-669.

Wright,C., \& Sparks, L.(1999). Loyalty Saturation Inretailing: Exploring The End of Retail Loyalty Cards?. International Journal of Retail \& Distribution Management, 27(11/10), 429-439.

Wu, H.W. (2002). The Factors Influencing The Supported Teams Chose by Professional Baseball Fans, and The Relationship Among Supporting Factors, Loyalty and Satisfaction. Education and Sports, Taiwan.

Yee, W.F., \& Sidek, Y. (2008). Influence of Brand Loyalty on Consumer Sportswear. International Journal of Economics and Management, 2(2), $221-236$.

Yi, Y., \& Jeon, H. (2003). Effects of Loyalty Programs on Value Perception, Program Loyalty, and Brand Loyalty. Journal of the Academy of Marketing Science, 31(3), 229-240.

Yoo, B., Donthu, N., \& Lee S. (2000). An Examination of Selected Marketing Mix Elements and Errand Equity. Journal of The Academic Marketing Science, 28(2), 195-211.

Zajonc, R.B. (1980). Feeling and Thinking: Preferences Need No Inferences. American Psychologist, 35, 151-175.

http://hubud.dephub.go.id/?id/aoc/index/page:2

http://www.dephub.go.id/berita/baca/jumlah-penumpang-angkutan-udara-2014mencapai 72,6-juta-orang/

http://www.tempo.co/read/news/2015/01/09/092/Langgar-Izin-Terbang-JonanBeri-Sanksi-5-Maskapai

http://keithnamariam.blogspot.com/2014/09/garuda-indonesia-airlines-danhrm.html

http://hubud.dephub.go.id/?id/news/detail/2366

www.garuda-indonesia.com

(http://industri.kontan.co.id). 